\title{
Effects of Combined Treatment with Vitamin D and COX2 Inhibitors on Breast Cancer Cell Lines
}

\author{
MICHAEL FRIEDRICH ${ }^{1}$, KATHRIN REICHERT $^{2}$, ALENA WOESTE $^{2}$, STEPHAN POLACK $^{2}$, \\ DOROTHEA FISCHER ${ }^{2}$, FRIEDERIKE HOELLEN ${ }^{2}$, ACHIM RODY $^{2}$, FRANK KÖSTER ${ }^{2}$ and MARC THILL ${ }^{3}$ \\ ${ }^{1}$ Department of Gynecology and Obstetrics, Helios Hospital Krefeld, Krefeld, Germany; \\ ${ }^{2}$ Department of Gynecology and Obstetrics, University of Lübeck, Lübeck, Germany; \\ ${ }^{3}$ Department of Gynecology and Obstetrics, Agaplesion Markus Hospital, Frankfurt am Main, Germany
}

\begin{abstract}
Background: Vitamin D is known for its anticancer potential. Prostaglandin $E_{2}\left(P G E_{2}\right)$ is a proliferative and inflammation-activating agent. The production of $P G E_{2}$ is dependent on the activity of cyclooxygenase-2 (COX2). A link between vitamin $D$ and $P G E_{2}$ metabolism was shown recently. Materials and Methods: In MDA-MB-231 and MCF-7 breast cancer cell lines, we investigated the influence of calcitriol and the COX2 inhibitor celecoxib on cell growth via the MTT test, as well as on the protein and mRNA expression of COX2 using western blot and quantitative real-time polymerase chain reaction ( $q R T-P C R)$. Results: The proliferation of MCF-7 and $M D A-M B-231$ was inhibited by both calcitriol and the COX2 inhibitor celecoxib and even more strongly by their combination. Moreover, calcitriol inhibited COX2 protein expression in MDA-MB-231 cells, as well as COX2 mRNA expression in both cell lines. Conclusion: The combination of calcitriol and celecoxib demonstrated a synergistic growthinhibitory effect in breast cancer cell lines.
\end{abstract}

The estimated annual incidence of breast cancer in the USA for 2014 for women is 232,670 , with an estimated 40,000 deaths (1). In 2010, 17,853 patients with breast cancer died in Germany (2). Thus, it is the most significant malignancy in females. Because of the increasing number of patients, there is an unmet need for new preventative strategies and new treatment approaches.

This article is freely accessible online.

Correspondence to: Michael Friedrich, Department of Gynecology and Obstetrics, HELIOS Hospital Krefeld, Lutherplatz 40, 47805 Krefeld, Germany. Tel: +49 2151322201, Fax: +49 2151322220. Email: michael.friedrich@helios-kliniken.de

Key Words: Vitamin D, celecoxib, cyclooxygenase-2, breast cancer MDA-MB-231 cells.
Many advances in breast cancer treatment have been made in the past decade. Many biological approaches have led to targeted and more effective treatment, and gene-expression profiling for a better understanding of breast cancer and its subgroups. Numerous new promising targets still warrant further exploration. Two of these targets are cyclooxygenase2 (COX2), the key enzyme required to convert arachidonic acid to prostaglandins (PG), and calcitriol [1,25dihydroxycholecalciferol or $\left.1,25-(\mathrm{OH})_{2} \mathrm{D}_{3}\right]$, which is the biologically active form of vitamin $\mathrm{D}(3)$.

Calcitriol is known to suppress cell growth, tumor growth and inhibit metastasis, as well as prolong survival in animal models (4). It particularly inhibits the growth of human breast cancer cell lines $(5,6)$. Multiple epidemiological studies have suggested that vitamin D has a protective effect against the carcinogenesis and progression of breast cancer (7-10). However, concerning the correlation between vitamin D intake and breast cancer risk, data are still conflicting (913). Calcitriol has been shown to exhibit significant antiinflammatory actions in breast cancer cells $(14,15)$. The proinflammatory PGs play an important role in the development and progression of breast cancer (16).

Increasing attention has been paid to the role of an inflammatory microenvironment in carcinogenesis. The interaction of inflammatory cytokines, growth factors and oncogene activation has been implicated in the fast induction of COX2 expression during carcinogenesis as COX2 affects tumor progression by participating in malignant proliferation, invasion and metastasis (17). High expression of COX2 is associated with increased proliferation, invasion, apoptotic resistance and angiogenesis $(18,19)$ and is, therefore, associated with a poor prognosis for patients with cancer (20).

Several epidemiological, preclinical and clinical studies support the idea that COX-targeting non-steroidal antiinflammatory drugs (NSAIDs) play protective roles against breast cancer (21-24). Consequently, we hypothesized that a combination of COX2 inhibition and calcitriol could exert 
an increased antiproliferative effect on breast cancer cells and could offer new preventative or treatment approaches in the future. A link between vitamin D and $\mathrm{PGE}_{2}$ metabolism $(25-27)$ was already proposed in breast cancer tissue $(28,29)$ in our recent publications.

The aim of the current study was to evaluate a possible synergistic activity of calcitriol, as the active form of vitamin $\mathrm{D}$, and the COX2 inhibitor celecoxib in breast cancer cells.

\section{Materials and Methods}

Cell culture. MCF-7 and MDA-MB-231 breast cancer cell lines were purchased from Leibniz-Institut DSMZ-Deutsche Sammlung von Mikroorganismen und Zellkulturen GmbH (Braunschweig, Germany). The cells were grown in RPMI 1640 (Life-Technologies, Darmstadt, Germany) supplemented with $10 \%$ fetal calf serum (FCS) and penicillin/streptomycin (both from PAA-Laboratories, Cölbe, Germany), at $37^{\circ} \mathrm{C}$ in a humidified atmosphere with $5 \% \mathrm{CO}_{2}$.

Growth experiments. To compare the proliferative rate between treated cells we used 3-(4,5-dimethylthiazol-2-yl)-2,5diphenyltetrazolium bromide (MTT)assays. Briefly, 3,000 cells/well were plated on a 96-well microplate. After $24 \mathrm{~h}$, the medium was changed to contain $3 \%$ FCS and test substances were added [calcitriol $(0.001,0.01,0.1,1$ and $10 \mu \mathrm{M})$, celecoxib $(1$ and $10 \mu \mathrm{M})$ and combination of calcitriol and celecoxib $(10 \mu \mathrm{M}$ calcitriol and $1 \mu \mathrm{M}$ celecoxib, $10 \mu \mathrm{M}$ calcitriol and $10 \mu \mathrm{M}$ celecoxib)], all of which were re-solved and diluted in dimethylsulfoxide (DMSO); 1,000 $\times$ stock solutions for calcitriol and $10,000 \times$ stock solution for celecoxib (both from Sigma, Taufkirchen, Germany). All solvent controls contained $0.1 \%$ DMSO. Six wells were treated for each concentration of each agent used. After $72 \mathrm{~h}$ of treatment, the medium was replaced by $10 \%$ MTT solution ( $5 \mathrm{mg} / \mathrm{ml}$ thiazolyl blue in PBS; Sigma) for a further 4-h incubation period. The reaction was then stopped and dissolution of formazan crystals was performed in the dark overnight by adding $100 \mu \mathrm{l}$ stop-solution (10\% (w/v) sodium dodecyl sulfate, $50 \% \mathrm{~N}, \mathrm{~N}$ dimethylformamide, $\mathrm{pH}$ 4.7). A microplate-reader (Dynatech Laboratories-MRX; DPC Biermann, Bad Nauheim, Germany) was used to measure the absorption of the wells at $560 \mathrm{~nm}$.

Protein expression. To compare the COX 2 protein expression, 300,000 cells were plated on 6-well plates in growth medium for 24 h. Afterwards, treatment with $0.1 \mu \mathrm{M}$ calcitriol, $1 \mu \mathrm{M}$ calcitriol, $1 \mu \mathrm{M}$ celecoxib and the combination of $1 \mu \mathrm{M}$ calcitriol and $1 \mu \mathrm{M}$ celecoxib was performed in media without FCS for $24 \mathrm{~h}$. Total protein was then extracted using MPER-buffer (GE Healthcare, München, Germany). Equal amounts of protein were analyzed in western blots with a monoclonal COX2 antibody (clone CX229; Biomol, Hamburg, Germany) and a $\beta$-actin antibody (clone AC-15; Sigma). Immunoreactive bands were detected with the Immobilon-WesternChemiluminescent-HRP-Substrate on Hyperfilm-ECL-PerformanceChemiluminescent-Film (both from GE Healthcare). The films were scanned and a densitometric analysis of the protein bands was performed using Easy-Win software (Herolab, Wiesloch, Germany).

Expression of COX2 mRNA. For the relative comparison of COX2 mRNA expression, quantitative reverse transcription polymerase chain reaction (qRT-PCR) was used. Therefore, 300,000 cells per well were plated on a 6-well plate in growth media and the media were replaced after $24 \mathrm{~h}$ by fresh media containing 3\% FCS together with agents. After $24 \mathrm{~h}$ of treatment, total RNA was isolated by using QIAzol (Qiagen, Hilden, Germany). For reverse transcription, $1 \mu \mathrm{g}$ RNA was used together with random primers and Superscript-II (Invitrogen, Karslruhe, Germany). For qPCR, Platinum-SYBR-Green-qPCR-Super-Mix-UDG (Invitrogen) was used. As primers for COX2, we used the Hs_PTGS2_1_SGQuantiTect-Primer-Assay (Qiagen) and for hypoxanthine-guanine phosphoribosyltranferase 1 (HPRT1), we used forward: 5'-TCA GGC AGT ATA ATC CAA AGA TGG T-3' and reverse: 5'-AGT CTG GCT TAT ATC CAA CAC TTC G-3' primers (synthesized at Metabion, Martinsried, Germany). The PCR protocol consisted of 42 cycles for $15 \mathrm{~s}$ at $95^{\circ} \mathrm{C}$ and $30 \mathrm{~s}$ at $60^{\circ} \mathrm{C}$. Each sample was tested in duplicates. Data were further processed with the Excel-based program REST-MCS ${ }^{\odot}$-version 2 (Qiagen).

\section{Results}

Treatment of breast cancer cell lines with calcitriol. Calcitriol reduced the growth of MCF-7 breast cancer cells significantly at concentrations between $100 \mathrm{nM}$ and $10 \mu \mathrm{M}$ to $71.5 \%$ and $36.8 \%$, respectively, compared to the solvent control (Figure 1A). The growth of MDA-MB-231 cells was also inhibited by $10 \mu \mathrm{M}$ calcitriol to $88.4 \%$ (Figure 1B).

Combined treatment with calcitriol and celecoxib. The growth of breast cancer cell lines was inhibited by $10 \mu \mathrm{M}$ calcitriol as already seen in the experiment above. Furthermore, growth was significantly inhibited by $10 \mu \mathrm{M}$ celecoxib in MCF-7 and MDA-MB-231 cells to $67.8 \%$ and $88.4 \%$, respectively. In MCF-7 cells, the effect of the combination of $10 \mu \mathrm{M}$ celecoxib and $10 \mu \mathrm{M}$ calcitriol was significantly stronger than that of calcitriol alone (Figure 2A) and of celecoxib alone (Figure 2A). Celecoxib at $1 \mu \mathrm{M}$ significantly reduced the growth of MCF-7 cells and, furthermore, the addition of $10 \mu \mathrm{M}$ calcitriol to $1 \mu \mathrm{M}$ celecoxib inhibited cell growth more than $1 \mu \mathrm{M}$ celecoxib alone (Figure 2A). In MDA-MB-231 cells, the combinations of $10 \mu \mathrm{M}$ celecoxib with $1 \mu \mathrm{M}$ calcitriol, as well as with 10 $\mu \mathrm{M}$ calcitriol, inhibited cell growth significantly more strongly than $10 \mu \mathrm{M}$ celecoxib alone and $10 \mu \mathrm{M}$ calcitriol alone (Figure 2B).

COX2 protein and $m R N A$ expression under the influence of calcitriol and celecoxib. COX2 protein was detected in western blots of proteins from MDA-MB-231 (Figure 3) but not MCF-7 cells. After $6 \mathrm{~h}$ of treatment with 0.1 or $1 \mu \mathrm{M}$ calcitriol, the density of the western blot signal for COX2 decreased at both concentrations to $62.7 \%$ compared to the solvent control. Celecoxib had no effect on COX2 protein expression and the combination of celecoxib and calcitriol reduced COX 2 protein to $87 \%$. The results were quantified using densitometry and normalized with the immunoreactive signals of $\beta$-actin. The COX 2 mRNA expression in MDA- 

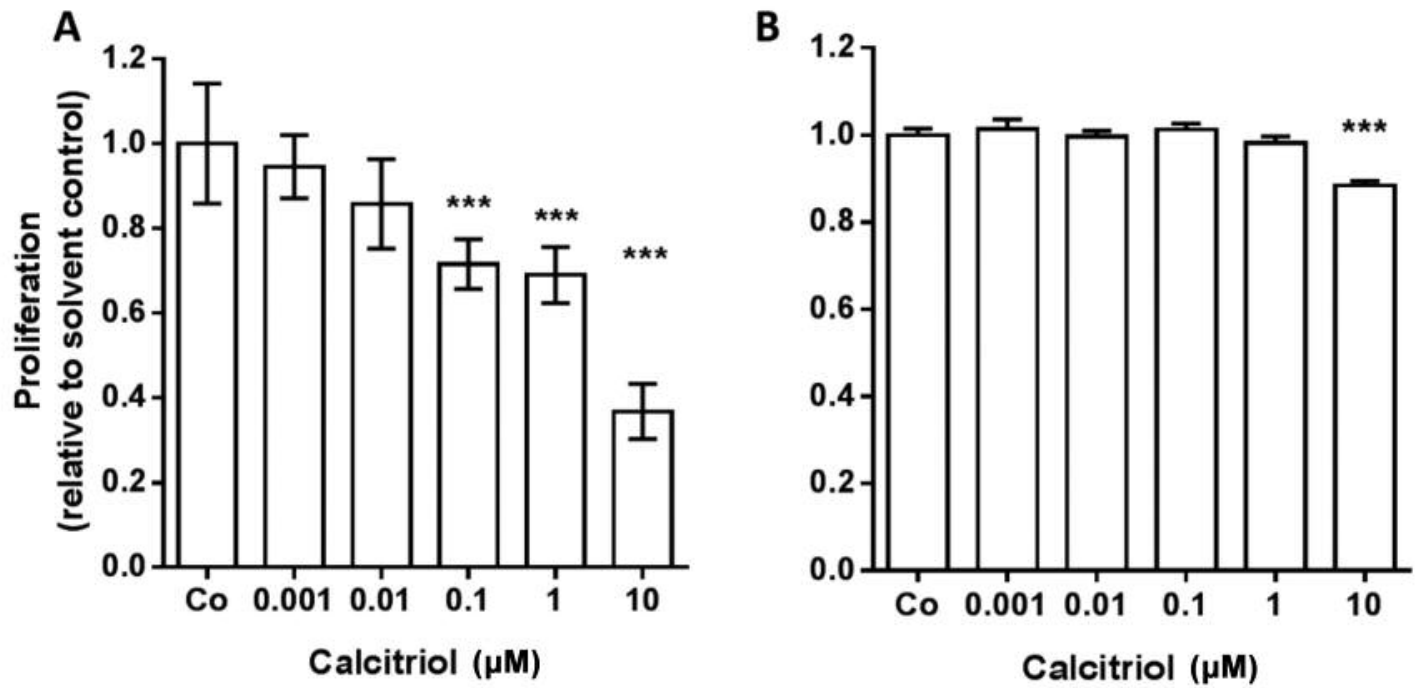

Figure 1. The influence of calcitriol on the growth of breast cancer cell lines. Cell growth of MCF-7 (A) and MDA-MB-231 (B) cells was assessed by the MTT assay after $72 \mathrm{~h}$ of treatment with different concentrations of calcitriol. The results are shown as the mean \pm SEM; statistical significance: $* * * p<0.001$. Co, Control.
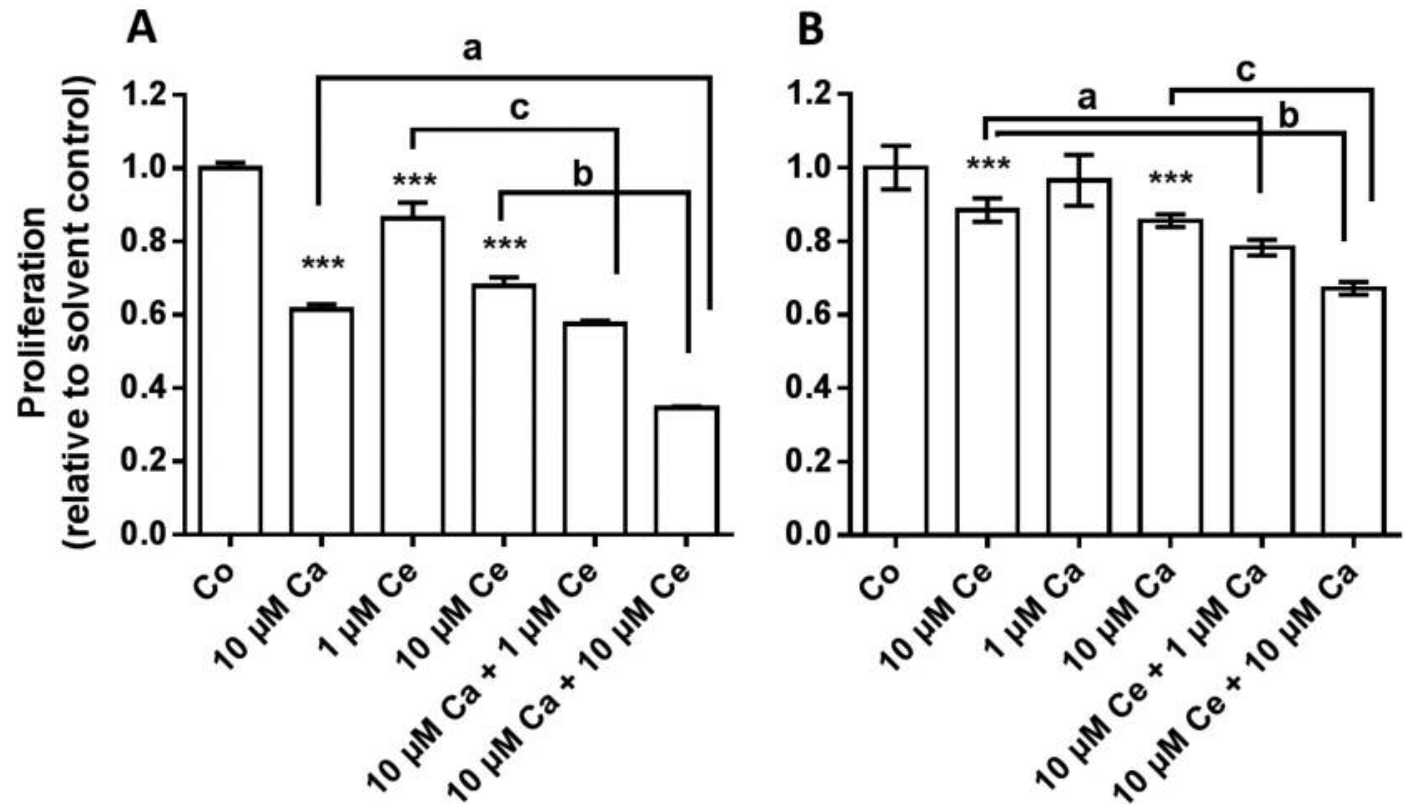

Figure 2. Combined treatment with calcitriol and celecoxib on MCF-7 (A) and MDA-MB-231 (B) cells. The proliferation is shown as the mean \pm SEM of cultures compared to the solvent-treated control. Statistical significance: $* * * p<0.001$. For the combined treatments, compared to single treatments: $A: a, b$ and $c=p<0.001$; and $B: a=p<0.01, b$ and $c=p<0.001$. Co, Control; Ca, calcitriol; Ce, celecoxib.

MB-231 and MCF-7 cells significantly decreased after 3-h treatment with celecoxib, as well as with calcitriol (Table I). It is remarkable that nearly the same decline in mRNA expression was found in both cell lines after treatment with celecoxib and calcitriol, because the expression of COX2 mRNA in MCF-7 cells seemed to be extremely low when compared with MDA-MB-231 cells. The latter statement is based on an estimation from the comparison of polymerase 


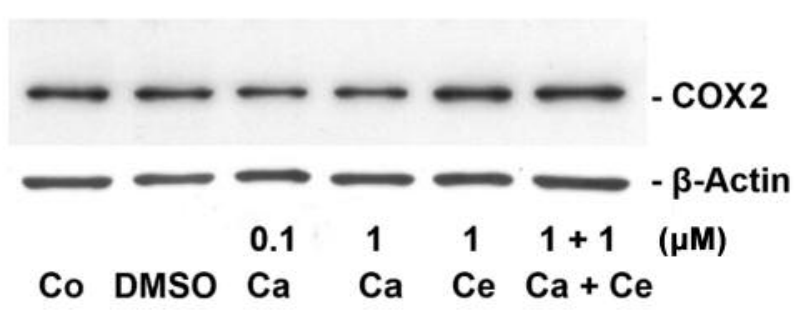

Figure 3. Cyclo-oxygenase 2 (COX2) protein expression in MDA-MB-231 cells after treatment with calcitriol and celecoxib. Western blot was carried out using COX2 antibody and $\beta$-actin as a loading control. Co, Control; Ca, calcitriol; Ce, celecoxib.

chain reaction cycle-time differences between the HPRTI and $C O X 2$ of both cell lines. The combined treatment with celecoxib and calcitriol hardly affected COX2 mRNA expression.

\section{Discussion}

In the present study, we observed an inhibition of proliferation in two breast cancer cell lines by both calcitriol and the selective COX2 inhibitor celecoxib. We also recorded an apparently additive inhibition under their combination. This additive inhibition in breast cancer cell lines was shown for the first time.

Colston and Hansen summarized several studies, clarifying that calcitriol can influence the cell cycle, cell differentiation, invasion and apoptosis of breast cancer cells in vitro (30). In a recently published study, we showed inhibition of breast cell proliferation by calcitriol in MDAMB-231, MCF-7 and MCF-10F cells (27). This is in line with data by Yuan et al. (17), who showed that 1,25$(\mathrm{OH})_{2} \mathrm{D}_{3}$ significantly inhibited the proliferation of MCF-7 cells in a time- and dose-dependent manner using MTT assays. In contrast to the results of Yuan et al., we used higher concentrations of calcitriol to receive comparable inhibitory effects, which might be explained by different growth conditions.

The main focus of our study was to treat breast cancer cell lines with the combination of calcitriol and the COX2 inhibitor celecoxib. The growth inhibition by celecoxib of breast cancer cell lines that we observed has been shown previously $(31,32)$; e.g. by Dai et al., who observed a timeand dose-dependent inhibition of proliferation in both MCF7 and MDA-MB-231. In contrast to Dai et al., we used lower concentrations of celecoxib and only one treatment time of $72 \mathrm{~h}$ (32). At $10 \mu \mathrm{M}$ celecoxib, we observed a reduction of proliferation comparable to that found by Dai et al. Furthermore, we combined the application of calcitriol with celecoxib, each at $10 \mu \mathrm{M}$ and observed significant additive
Table I. Measurement of cyclo-oxygenase 2 (COX2) mRNA after treatment with calcitriol and celecoxib. Results are the mean \pm SEM of treated cells versus the untreated solvent control.

\begin{tabular}{lccc}
\hline & Celecoxib & Calcitriol & Celecoxib+calcitriol \\
\hline MCF-7 & $0.78 \pm 0.19$ & $0.59 \pm 0.23$ & $0.95 \pm 0.29$ \\
MDA-MB-231 & $0.78 \pm 0.32$ & $0.58 \pm 0.24$ & $1.17 \pm 0.37$ \\
\hline
\end{tabular}

antiproliferative effects compared to each of the single applications. Therefore, we suggest that the combination of both substances might be a valuable tool for the targeted treatment of breast cancer cells.

A further interesting question was to examine the connection, if any, between the vitamin D and PG pathways. Therefore, we measured COX2, the central PG-synthesizing enzyme, after treatment with calcitriol. A decrease of the COX2 protein content in MDA-MB-231 cells, as well as in the mRNA level in both tested breast cancer cell lines was found. Yuan et al. also addressed this issue (17) and showed a decrease of COX2 protein in MCF-7 cells; we did rot detect COX2 protein in MCF-7 cells. Why Yuan et al. were able to detect COX2 by western blot and we were not, might be due to a different version of the cell line or different culture conditions. For us, it did not seem to be unusual that the COX2 protein content in MCF-7 was under the level of detection, since we estimated the $C O X 2$ mRNA level relative to HPRT1 to be approximately 1,000 times lower compared to that in MDA-MB-231 cells. After treatment with celecoxib, the COX2 protein level decreased in MDA-MB231 cells. Moreover, celecoxib seemed to counteract the inhibitory effect of calcitriol. Regarding COX2 mRNA, our results are in line with Dai et al. showing a decrease in COX2 mRNA after treatment with celecoxi. However, in our study, mRNA was analyzed after $6 \mathrm{~h}$ and in the study of Dai et al. after $48 \mathrm{~h}$ (32).

Down-regulation of COX2 expression by calcitriol is an important issue in breast cancer, because it limits the synthesis and biological actions of pro-inflammatory PGs (5).

Epidemiological studies support a protective effect of vitamin D. In a recently published meta-analysis, the authors concluded that a low blood level of calcitriol was associated with an increased risk of recurrence and death of patients with breast cancer (10). However, regarding the prevention of breast cancer by vitamin D supplementation, data are conflicting. While in the results of the meta-analysis by Sperati et al. vitamin D supplementation did reduce the breast cancer risk (13), Chen et al. stated an inverse relationship between vitamin D intake and breast cancer risk (33).

To date, calcitriol has been evaluated in a number of preclinical and some clinical studies as an antitumor agent 
in different carcinomas [reviewed in Trump et al. (34)]. The maximum tolerated dose of calcitriol is still unclear and calcitriol is recommended to be used restrictively due to its potentially hypercalcemic impact $(35,36)$. Only a sparse number of clinical trials regarding the use of calcitriol in combination with chemotherapy for cancer treatment exist with dissatisfactory results (34). The ASCENT-I-Trial (AIPC Study of Calcitriol Enhancing Taxotere) evaluated the combination of docetaxel and calcitriol in patients with pretreated and advanced prostate cancer but the study was stopped because the treatment arm was associated with shorter survival than the control arm (37).

The importance of COX inhibitors is widely recognized, since they suppress breast cancer cell growth both in vivo and in vitro $(16,38)$. The inhibition of COX2 by the selective inhibitor celecoxib apparently inactivates the transcription of aromatase and thereby inhibits the proliferation of tumor cells in estrogen-responsive breast cancer (39). Furthermore, celecoxib is able to induce apoptosis in different types of cancer (40). Epidemiological studies support the hypothesis of breast cancer prevention by NSAID administration. Several studies, including one meta-analysis, reported a reduction of breast cancer risk after NSAID use of between $16 \%$ and $40 \%(23,24,41,42)$. In different murine models for breast cancer, celecoxib reduced tumor growth, increased apoptosis and reduced neoangiogenesis $(43,44)$.

The correlation between COX2 and estrogen metabolism is an important issue. The inhibition of aromatase expression due to COX2 inhibition is an interesting therapeutic strategy. Several clinical trials have been conducted to investigate the use of COX2 inhibitors regarding their impact on breast cancer. The German Breast Group completed a multicenter clinical phase III study, the REACT trial, which analyzed the combination of endocrine treatment and celecoxib in primary breast cancer (www.gbg.de). Various other combination therapies with COX2 inhibitors regarding the metastatic setting were completed with inconsistent data (45-48). In a preoperative decision-making setting, two studies were recently published $(49,50)$ : In the study by Brandao et al., patients with breast cancer were randomized to receive either pre-operative $400 \mathrm{mg}$ celecoxib twice daily for 2 to 3 weeks or placebo. The impact on proliferation was reflected by a reduction of Ki-67-positive cells (49). However, in a similar setting, Martin et al. found no statistically significant changes in Ki-67 expression. (50). The first data suggest a possible treatment approach for combination of COX2 inhibitors and calcitriol in breast cancer (25) as both PG and calcitriol metabolism influence carcinogenesis and tumor growth. The metabolism of calcitriol and prostaglandin is linked by various factors and thus a synergistic effect might be supposed. The group of Moreno et al. demonstrated growth inhibition in prostate cancer cells by COX2 inhibitors and calcitriol. They used benign and malignant prostate cell lines and illustrated that calcitriol inhibits the PG-dependent proliferation of prostate cancer cells. Moreover, the authors showed that a combination of calcitriol with a COX2 inhibitor had a synergistic effect on the growth inhibition of prostate cancer cells (51).

We conclude that the combination of the COX2 inhibitor celecoxib and calcitriol cooperatively inhibits the growth of breast cancer cell lines. Calcitriol reduces aromatase expression by direct repression, as well as via an indirect effect due to reduction in the levels of PGs (5), and celecoxib supports this suppressive effect on estrogen synthesis. Therefore, we suggest a therapeutic role of the combination of celecoxib and calcitriol in hormone receptor-positive breast cancer, probably with the addition of an aromatase inhibitor. Based on our findings, we believe that it is worth considering prospective clinical trials showing the beneficial actions of celecoxib and calcitriol in endocrine-responsive breast cancer.

\section{References}

1 Cancer Facts \& Figures 2014. American Cancer Society, Atlanta, 2014.

2 Krebs in Deutschland 2009/2010., Vol. 9 (Robert Koch-Institut (Hrsg) und die Gesellschaft der epidemiologischen Krebsregister in Deutschland e.V. (Hrsg)., Berlin, 2013.

3 Thill M, Terjung A and Friedrich M: Breast cancer-new aspects of tumor biology: Are calcitriol and cyclooxygenase-2 possible targets for breast cancer? Eur J Gynaecol Oncol 35: 341-358, 2014.

4 Honma Y, Hozumi M, Abe E, Konno K, Fukushima M, Hata S, Nishii Y, DeLuca HF and Suda T: $1 \alpha, 25$-Dihydroxyvitamin $\mathrm{D}_{3}$ and $1 \alpha$-hydroxyvitamin $D_{3}$ prolong survival time of mice inoculated with myeloid leukemia cells. Proc Natl Acad Sci USA 80: 201-204, 1983.

5 Krishnan AV, Swami S and Feldman D: The potential therapeutic benefits of vitamin $\mathrm{D}$ in the treatment of estrogen receptorpositive breast cancer. Steroids 77: 1107-1112, 2012.

6 Welsh J, Wietzke JA, Zinser GM, Smyczek S, Romu S, Tribble E, Welsh JC, Byrne B and Narvaez CJ: Impact of the vitamin D3 receptor on growth-regulatory pathways in mammary gland and breast cancer. J Steroid Biochem Mol Biol 83: 85-92, 2002.

7 Goodwin PJ, Ennis M, Pritchard KI, Koo J and Hood N: Prognostic effects of 25-hydroxyvitamin D levels in early breast cancer. J Clin Oncol 27: 3757-3763, 2009.

8 Janowsky EC, Lester GE, Weinberg CR, Millikan RC, Schildkraut JM, Garrett PA and Hulka BS: Association between low levels of 1,25-dihydroxyvitamin D and breast cancer risk. Public Health Nutr 2: 283-291, 1999.

9 Kim Y and Je Y: Vitamin D intake, blood 25(OH)D levels, and breast cancer risk or mortality: a meta-analysis. Br J Cancer 110: 2772-2784, 2014.

10 Rose AA, Elser C, Ennis M and Goodwin PJ: Blood levels of vitamin $\mathrm{D}$ and early-stage breast cancer prognosis: a systematic review and meta-analysis. Breast Cancer Res Treat 141: 331339, 2013. 
11 McCullough ML, Rodriguez C, Diver WR, Feigelson HS, Stevens VL, Thun MJ and Calle EE: Dairy, calcium, and vitamin $\mathrm{D}$ intake and postmenopausal breast cancer risk in the Cancer Prevention Study II Nutrition Cohort. Cancer Epidemiol Biomarkers Prev 14: 2898-2904, 2005.

12 Rossi M, McLaughlin JK, Lagiou P, Bosetti C, Talamini R, Lipworth L, Giacosa A, Montella M, Franceschi S, Negri E and La Vecchia C: Vitamin D intake and breast cancer risk: a case-control study in Italy. Ann Oncol 20: 374-378, 2009.

13 Sperati F, Vici P, Maugeri-Sacca M, Stranges S, Santesso N, Mariani L, Giordano A, Sergi D, Pizzuti L, Di Lauro L, Montella M, Crispo A, Mottolese M and Barba M: Vitamin D supplementation and breast cancer prevention: a systematic review and meta-analysis of randomized clinical trials. PLoS One 8: e69269, 2013.

14 Krishnan AV and Feldman D: Mechanisms of the anticancer and anti-inflammatory actions of vitamin D. Annu Rev Pharmacol Toxicol 51: 311-336, 2011.

15 Krishnan AV, Trump DL, Johnson CS and Feldman D: The role of vitamin $\mathrm{D}$ in cancer prevention and treatment. Endocrinol Metab Clin North Am 39: 401-418, 2010.

16 Hoellen F, Kelling K, Dittmer C, Diedrich K, Friedrich M and Thill M: Impact of cyclooxygenase-2 in breast cancer. Anticancer Res 31: 4359-4367, 2011.

17 Yuan L, Jiang R, Yang Y, Ding $\mathrm{S}$ and Deng H: 1,25Dihydroxyvitamin D3 inhibits growth of the breast cancer cell line MCF-7 and down-regulates cytochrome P4501B1 through the COX2/PGE2 pathway. Oncol Rep 28: 2131-2137, 2012.

18 Chang SH, Liu CH, Conway R, Han DK, Nithipatikom K, Trifan OC, Lane TF and Hla T: Role of prostaglandin $\mathrm{E}_{2}$-dependent angiogenic switch in cyclooxygenase 2-induced breast cancer progression. Proc Natl Acad Sci USA 101: 591-596, 2004.

19 Zha S, Yegnasubramanian V, Nelson WG, Isaacs WB and De Marzo AM: Cyclo-oxygenases in cancer: progress and perspective. Cancer Lett 215: 1-20, 2004.

20 Ristimaki A, Sivula A, Lundin J, Lundin M, Salminen T, Haglund $\mathrm{C}$, Joensuu $\mathrm{H}$ and Isola J: Prognostic significance of elevated cyclo-oxygenase- 2 expression in breast cancer. Cancer Res 62: 632-635, 2002.

21 Allott EH, Tse CK, Olshan AF, Carey LA, Moorman PG and Troester MA: Non-steroidal anti-inflammatory drug use, hormone receptor status, and breast cancer-specific mortality in the Carolina Breast Cancer Study. Breast Cancer Res Treat 147: 415-421, 2014.

22 Harris RE, Chlebowski RT, Jackson RD, Frid DJ, Ascenseo JL, Anderson G, Loar A, Rodabough RJ, White E and McTiernan A: Breast cancer and nonsteroidal anti-inflammatory drugs: prospective results from the Women's Health Initiative. Cancer Res 63: 6096-6101, 2003.

23 Harris RE, Namboodiri KK and Farrar WB: Nonsteroidal antiinflammatory drugs and breast cancer. Epidemiology 7: 203$205,1996$.

24 Sharpe CR, Collet JP, McNutt M, Belzile E, Boivin JF and Hanley JA: Nested case-control study of the effects of nonsteroidal anti-inflammatory drugs on breast cancer risk and stage. Br J Cancer 83: 112-120, 2000.

25 Thill M, Hoellen F, Becker S, Dittmer C, Fischer D, Kummel S, Salehin D, Friedrich M, Koster F, Diedrich K and Cordes T: Expression of prostaglandin- and vitamin D-metabolising enzymes in benign and malignant breast cells. Anticancer Res 32: 367-372, 2012.
26 Fischer D, Thome M, Becker S, Cordes T, Diedrich K, Friedrich $\mathrm{M}$ and Thill M: 25-Hydroxyvitamin D3 1alpha-hydroxylase splice variants in benign and malignant ovarian cell lines and tissue. Anticancer Res 29: 3627-3633, 2009.

27 Thill M, Cordes T, Hoellen F, Becker S, Dittmer C, Kummel S, Salehin D, Friedrich M, Diedrich K and Koster F: Influence of calcitriol on prostaglandin- and vitamin D-metabolising enzymes in benign and malignant breast cell lines. Anticancer Res 32: 359-365, 2012.

28 Cordes T, Hoellen F, Dittmer C, Salehin D, Kummel S, Friedrich M, Koster F, Becker S, Diedrich K and Thill M: Correlation of prostaglandin metabolizing enzymes and serum $\mathrm{PGE}_{2}$ levels with vitamin $\mathrm{D}$ receptor and serum $25(\mathrm{OH})_{2} \mathrm{D}_{3}$ levels in breast and ovarian cancer. Anticancer Res 32: 351-357, 2012.

29 Thill M, Fischer D, Kelling K, Hoellen F, Dittmer C, Hornemann A, Salehin D, Diedrich K, Friedrich M and Becker $\mathrm{S}$ : Expression of vitamin D receptor (VDR), cyclooxygenase-2 (COX2) and 15-hydroxyprostaglandin dehydrogenase (15$\mathrm{PGDH})$ in benign and malignant ovarian tissue and 25hydroxycholecalciferol $\left(25\left(\mathrm{OH}_{2}\right) \mathrm{D}_{3}\right)$ and prostaglandin $\mathrm{E}_{2}$ $\left(\mathrm{PGE}_{2}\right)$ serum level in ovarian cancer patients. J Steroid Biochem Mol Biol 121: 387-390, 2010.

30 Colston KW and Hansen CM: Mechanisms implicated in the growth regulatory effects of vitamin D in breast cancer. Endocr Relat Cancer 9: 45-59, 2002.

31 Bocca C, Bozzo F, Bassignana A and Miglietta A: Antiproliferative effects of COX2 inhibitor celecoxib on human breast cancer cell lines. Mol Cell Biochem 350: 59-70, 2011.

32 Dai ZJ, Ma XB, Kang HF, Gao J, Min WL, Guan HT, Diao Y, Lu WF and Wang XJ: Antitumor activity of the selective cyclooxygenase-2 inhibitor, celecoxib, on breast cancer in vitro and in vivo. Cancer Cell Int 12: 53, 2012.

33 Chen P, Hu P, Xie D, Qin Y, Wang F and Wang H: Meta-analysis of vitamin D, calcium and the prevention of breast cancer. Breast Cancer Res Treat 121: 469-477, 2010.

34 Trump DL, Deeb KK and Johnson CS: Vitamin D: considerations in the continued development as an agent for cancer prevention and therapy. Cancer J 16: 1-9, 2010.

35 Aparna R, Subhashini J, Roy KR, Reddy GS, Robinson M, Uskokovic MR, Venkateswara Reddy G and Reddanna P: Selective inhibition of cyclooxygenase-2 (COX2) by 1alpha,25dihydroxy-16-ene-23-yne-vitamin $\mathrm{D}_{3}$, a less calcemic vitamin $\mathrm{D}$ analog. J Cell Biochem 104: 1832-1842, 2008.

36 Masuda S and Jones G: Promise of vitamin D analogues in the treatment of hyperproliferative conditions. Mol Cancer Ther 5: 797-808, 2006.

37 Scher HI, Jia X, Chi K, de Wit R, Berry WR, Albers P, Henick B, Waterhouse D, Ruether DJ, Rosen PJ, Meluch AA, Nordquist LT, Venner PM, Heidenreich A, Chu L and Heller G: Randomized, open-label phase III trial of docetaxel plus high-dose calcitriol versus docetaxel plus prednisone for patients with castrationresistant prostate cancer. J Clin Oncol 29: 2191-2198, 2011.

38 Rozic JG, Chakraborty C and Lala PK: Cyclooxygenase inhibitors retard murine mammary tumor progression by reducing tumor cell migration, invasiveness and angiogenesis. Int J Cancer 93: 497-506, 2001.

39 Diaz-Cruz ES, Shapiro CL and Brueggemeier RW: Cyclooxygenase inhibitors suppress aromatase expression and activity in breast cancer cells. J Clin Endocrinol Metab 90: 2563$2570,2005$. 
40 Jendrossek V: Targeting apoptosis pathways by Celecoxib in cancer. Cancer Lett 332: 313-324, 2013.

41 Ashok V, Dash C, Rohan TE, Sprafka JM and Terry PD: Selective cyclooxygenase-2 (COX2) inhibitors and breast cancer risk. Breast 20: 66-70, 2011.

42 Khuder SA and Mutgi AB: Breast cancer and NSAID use: a meta-analysis. Br J Cancer 84: 1188-1192, 2001.

43 Barnes NL, Warnberg F, Farnie G, White D, Jiang W, Anderson $\mathrm{E}$ and Bundred NJ: Cyclooxygenase-2 inhibition: effects on tumour growth, cell cycling and lymphangiogenesis in a xenograft model of breast cancer. Br J Cancer 96: 575-582, 2007.

44 Yoshinaka R, Shibata MA, Morimoto J, Tanigawa N and Otsuki $\mathrm{Y}$ : COX2 inhibitor celecoxib suppresses tumor growth and lung metastasis of a murine mammary cancer. Anticancer Res 26: 4245-4254, 2006.

45 Canney PA, Machin MA and Curto J: A feasibility study of the efficacy and tolerability of the combination of Exemestane with the COX2 inhibitor Celecoxib in post-menopausal patients with advanced breast cancer. Eur J Cancer 42: 2751-2756, 2006.

46 Chow LW, Yip AY, Loo WT, Lam CK and Toi M: Celecoxib anti-aromatase neoadjuvant (CAAN) trial for locally advanced breast cancer. J Steroid Biochem Mol Biol 111: 13-17, 2008.

47 Dirix LY, Ignacio J, Nag S, Bapsy P, Gomez H, Raghunadharao D, Paridaens R, Jones S, Falcon S, Carpentieri M, Abbattista A and Lobelle JP: Treatment of advanced hormone-sensitive breast cancer in postmenopausal women with exemestane alone or in combination with celecoxib. J Clin Oncol 26: 1253-1259, 2008.
48 Falandry C, Debled M, Bachelot T, Delozier T, Cretin J, Romestaing P, Mille D, You B, Mauriac L, Pujade-Lauraine E and Freyer G: Celecoxib and exemestane versus placebo and exemestane in postmenopausal metastatic breast cancer patients: a double-blind phase III GINECO study. Breast Cancer Res Treat 116: 501-508, 2009.

49 Brandao RD, Veeck J, Van de Vijver KK, Lindsey P, de Vries B, van Elssen CH, Blok MJ, Keymeulen K, Ayoubi T, Smeets HJ, Tjan-Heijnen VC and Hupperets PS: A randomised controlled phase II trial of pre-operative celecoxib treatment reveals antitumour transcriptional response in primary breast cancer. Breast Cancer Res 15: R29, 2013.

50 Martin LA, Davies GL, Weigel MT, Betambeau N, Hills MJ, Salter J, Walsh G, A'Hern R and Dowsett M: Pre-surgical study of the biological effects of the selective cyclo-oxygenase-2 inhibitor celecoxib in patients with primary breast cancer. Breast Cancer Res Treat 123: 829-836, 2010.

51 Moreno J, Krishnan AV, Swami S, Nonn L, Peehl DM and Feldman D: Regulation of prostaglandin metabolism by calcitriol attenuates growth stimulation in prostate cancer cells. Cancer Res 65: 7917-7925, 2005
Received October 31, 2017

Revised December 18, 2017

Accepted December 29, 2017 